\title{
Schwann cell dysfunction in uraemia
}

\author{
J. J. DINN AND D. L. CRANE \\ From the School of Pathology, Trinity College, Dublin
}

SUMMARY Examination of individual sural nerve fibres revealed segmental demyelination, in 10 out of 12 subjects with uraemia. Peripheral neuropathy was present in only two cases. The complex biochemical changes occurring with dialysis unmask the underlying demyelination in subjects with a latent neuropathy. This would explain the precipitation of a neuropathy in those subjects submitted for repeated dialysis. The possible correlation between creatinine retention, dialysis, and metabolic dysfunction in the Schwann cell system is discussed.

Disturbed neural function often accompanies renal failure, yet it is only in recent years that uraemia has been recognized as a primary factor in the production of peripheral neuropathy. The frequency is variously reported from 13 to $86 \%$ but is, in general, higher where dialysis is actively employed (Tenckhoff, Boen, Jebsen, and Spiegler, 1965; Jebsen, Tenckhoff, and Honet, 1967). Latent or subclinical neuropathy is also common, with a majority of subjects affected by chronic renal failure exhibiting mild to marked reduction of nerve conduction velocity (Preswick and Jeremy, 1964; Callaghan, 1966).

The clinical manifestations of uraemic neuropathy are now well documented (Tyler, 1968), but the underlying pathology is uncertain and the aetiology unknown. The essential pathological lesion noted in long-standing, severe renal failure complicated by neuropathy consists of destruction to both myelin sheaths and axis cylinders (Asbury, Victor, and Adams, 1963). However, several inconsistencies exist if Wallerian degeneration is the basic lesion in every case. The marked diminution of nerve conduction velocity, the rapid change in neurological status frequently following dialysis or transplantation, and the selective damage to small nerve fibres in the burning-foot syndrome all tend to favour segmental demyelination as the underlying lesion. This patchy demyelination of the peripheral nervous system is found in many metabolic disorders (McDonald, 1969) and it would be reasonable to assume that uraemia, with its complex biochemical alterations, likewise predisposes to abnormalities in the Schwann cell system.

Consequently, this investigation was undertaken to ascertain if segmental demyelination is found in association with uraemia.
MATERIALS AND METHODS

Sural nerves, obtained at necropsy from 12 subjects with varying degrees and duration of uraemia, were examined. The clinical and pathological details of the cases are summarized in the Table.

The three-centimetre portions of sural nerve were suspended in $10 \%$ formalin with a $2 \mathrm{~g}$ weight attached. The weight prevents wrinkling of the individual nerve fibres. Conventional preparations included transverse sections of nerve stained with haematoxylin and eosin, elastic with van Gieson, and Glees-Marsland method for axis cylinders. The method of choice for demonstrating the presence of segmental loss of myelin is by examination of suitable lengths of single nerve fibres. Consequently, the remaining portion of nerve was stained with $1 \%$ osmium tetroxide, macerated in $60 \%$ glycerol, and the individual nerve fibres teased out in the manner described by Vizoso and Young (1948). The fibres so obtained were cleared in creosote before mounting. Measurements of internodal length and fibre diameter were made with an eyepiece micrometer.

\section{RESULTS}

Routine histological preparations revealed no abnormalities. Axis cylinders were represented equally in all areas examined. Transverse sections of the osmium tetroxide stained nerve revealed a moderate loss of myelinated fibres in case 7 only.

From each nerve, 25 to 30 single nerve fibres, picked indiscriminately, were teased out and examined. In cases 2 and 4, both with uraemia of sudden onset and short duration, no loss of myelin was evident. In the 10 remaining cases, all revealed segmental demyelination. The changes varied from widening of the nodes of Ranvier to partial or complete loss of myelin along the whole of an internodal 
TABLE

SUMMARY OF THE CLINICAL AND PATHOLOGICAL DATA

\begin{tabular}{|c|c|c|c|c|c|c|c|}
\hline \multirow[t]{2}{*}{ Case } & \multirow{2}{*}{$\begin{array}{l}\text { Age } \\
(y r)\end{array}$} & \multirow[t]{2}{*}{$\operatorname{Sex}$} & \multirow{2}{*}{$\begin{array}{l}\text { Duration of } \\
\text { uraemia }\end{array}$} & \multicolumn{2}{|r|}{ Laboratory findings } & \multirow{2}{*}{$\begin{array}{c}\text { Kidney } \\
\text { pathology }\end{array}$} & \multirow[t]{2}{*}{ Comments } \\
\hline & & & & $\begin{array}{l}\text { Blood urea } \\
(\mathrm{mg} / 100 \mathrm{ml} .)\end{array}$ & Others & & \\
\hline 1 & 26 & $\mathbf{M}$ & Acute & 400 & $\begin{array}{c}\mathrm{Na} \mathrm{136,} \mathrm{K} \mathrm{6.6,} \mathrm{Cl} 93 \mathrm{~m} \text {-equiv/l. } \\
\text { Alk. reserve } 21 \cdot 5 \\
\text { Creatinine } 9.5 \mathrm{mg} / 100 \mathrm{ml} .\end{array}$ & Tubular necrosis & $\begin{array}{l}\text { Anuria after traffic accident, haemo- } \\
\text { dialysis, segmental demyelination }\end{array}$ \\
\hline 2 & 75 & $\mathbf{M}$ & Acute & 617 & $\begin{array}{l}\mathrm{Na} 129, \mathrm{~K} 5 \cdot 8, \mathrm{Cl} 86 \mathrm{~m} \text {-equiv/l. } \\
\mathrm{Ca} 7 \cdot 8, \mathrm{P} 11 \mathrm{mg} / 100 \mathrm{ml} \text {., pH } 7 \cdot 2\end{array}$ & Tubular necrosis & Myocardial infarction \\
\hline 3 & 48 & $\mathbf{F}$ & Chronic & 400 & Urinary tract infection & $\begin{array}{l}\text { Malignant } \\
\text { nephrosclerosis }\end{array}$ & Malignant $\begin{array}{c}\text { hypertension, segmental } \\
\text { demyelination }\end{array}$ \\
\hline 4 & 50 & $\mathbf{M}$ & Acute & 400 & 一 & Amyloidosis & $\begin{array}{c}\text { Oliguria after intestinal obstruction, } \\
\text { haemodialysis }\end{array}$ \\
\hline 5 & 40 & $\mathbf{M}$ & Acute & 240 & K 5 m-equiv/1. & None & $\begin{array}{c}\text { Peripheral neuropathy, alcoholic, } \\
\text { haemodialysis, segmental } \\
\text { demyelination }\end{array}$ \\
\hline 6 & 61 & $\mathbf{M}$ & Chronic & 420 & $\mathrm{Na} 134, \mathrm{~K} 6 \mathrm{~m}$-equiv/l. & $\begin{array}{l}\text { Chronic glomer- } \\
\text { ulonephritis }\end{array}$ & Segmental demyelination \\
\hline 7 & 27 & $\mathbf{F}$ & Chronic & 300 & $\begin{array}{l}\mathrm{Na} 136, \mathrm{~K} 2 \cdot 7, \mathrm{Cl} 97 \mathrm{~m} \text {-equiv/1., } \\
\mathrm{Ca} 6 \cdot 7 \text {, creatinine } 13.4 \mathrm{mg} / 100 \mathrm{ml} \text {. }\end{array}$ & $\begin{array}{l}\text { Bilateral chronic } \\
\text { pyelonephritis, } \\
\text { renal calculi }\end{array}$ & $\begin{array}{l}\text { Peripheral neuropathy, haemodialysis, } \\
\text { left kidney transplant, segmental } \\
\text { demyelination }\end{array}$ \\
\hline 8 & 64 & $\mathbf{M}$ & Chronic & 310 & $\mathrm{Na} 138, \mathrm{~K} \mathrm{3 \cdot 7,} \mathrm{Cl} 79$ m-equiv/l. & ? No necropsy & $\begin{array}{l}\text { Left nephrectomy, hypertension, di- } \\
\text { alysis, segmental demyelination }\end{array}$ \\
\hline 9 & 72 & $\mathbf{M}$ & Acute & 380 & $\begin{array}{c}\mathrm{Na} 140, \mathrm{~K} 5 \cdot 8, \mathrm{Cl} 107 \mathrm{~m} \text {-equiv/l. } \\
\text { pH } 7.45\end{array}$ & Tubular necrosis & $\begin{array}{c}\text { ? transfusion reaction, dialysis, seg- } \\
\text { mental demyelination }\end{array}$ \\
\hline 10 & 30 & $\mathbf{M}$ & Chronic & 395 & $\begin{array}{c}\mathrm{K} 7 \mathrm{~m} \text {-equiv } / 1 ., \text { creatinine } 15 \\
\mathrm{mg} / 100 \mathrm{ml} .\end{array}$ & $\begin{array}{l}\text { Pyonephrosis, } \\
\text { malignant } \\
\text { nephrosclerosis }\end{array}$ & $\begin{array}{l}\text { Epispadias, ureto-colic transplant, } \\
\text { malignant hypertension, dialysis, segg } \\
\text { mental demyelination }\end{array}$ \\
\hline 11 & 60 & $\mathbf{F}$ & Chronic & 400 & Ca $5.8 \mathrm{mg} / 100 \mathrm{ml}$ & Polycystic & $\begin{array}{l}\text { Polycystic disease, multiple ber } \\
\text { aneurysms, segmental demyelination }\end{array}$ \\
\hline 12 & 40 & $\mathbf{F}$ & Chronic & 230 & $\begin{array}{l}\mathrm{Na} 129, \mathrm{~K} 6.6, \mathrm{Cl} 92 \mathrm{~m} \text {-equiv/l. } \\
\text { creatinine } 7.6 \mathrm{mg} / 100 \mathrm{ml} .\end{array}$ & $\begin{array}{c}\text { Malignant } \\
\text { nephrosclerosis }\end{array}$ & $\begin{array}{c}\text { Malignant hypertension, dialysis, seg? } \\
\text { mental demyelination }\end{array}$ \\
\hline
\end{tabular}

segment (Fig. 1). The degree of demyelination, while difficult to analyse quantitatively, was more extensive in those subjects with uraemia of long duration, in those submitted for dialysis, and in the two cases (5 and 7) with peripheral neuropathy.

Remyelination of the denuded axons results in short, thinly myelinated segments of reduced diameter (Fig. 2). These segments remain as such and are a permanent record of previous Schwann cell damage. Remyelinated segments were noted in every case, being more numerous in those subjects dialysed.

Occasional fibres were observed which consisted of endoneurial tubes containing discrete osmophilic ovoids, indicating destruction to both myelin and axis cylinders. These fibres were found particularly in the two cases with peripheral neuropathy.

A graphic analysis of the pathological findings is obtained if internodal length is plotted against maximum fibre diameter, in the method suggested by Fullerton, Gilliatt, Lascelles, and Morgan-Hughes (1965). Figures 3 and 4 illustrate the wide scatter of points, characteristic of segmental demyelination. The normal linear relationship between internodal length and fibre diameter (Lascelles and Thomas, 1966) is irrevocably lost. In each of the 10 cases with segmental demyelination, a similar scatter was observed.

\section{DISCUSSION}

The presence of segmental demyelination associated with uraemia in 10 out of the 12 cases examined provides evidence that renal failure initiates a metabolic dysfunction in the Schwann cell system. The majority of subjects exhibited latent neurological damage since peripheral neuropathy was detected in only two cases. This concept of a latent or subclinical neuropathy has important implications. Obviously the Schwann cells, already compromised by uraemia, become especially susceptible to sudden metabolic derangements. The precipitation of a neuropathy or a worsening of an existing uraemic 


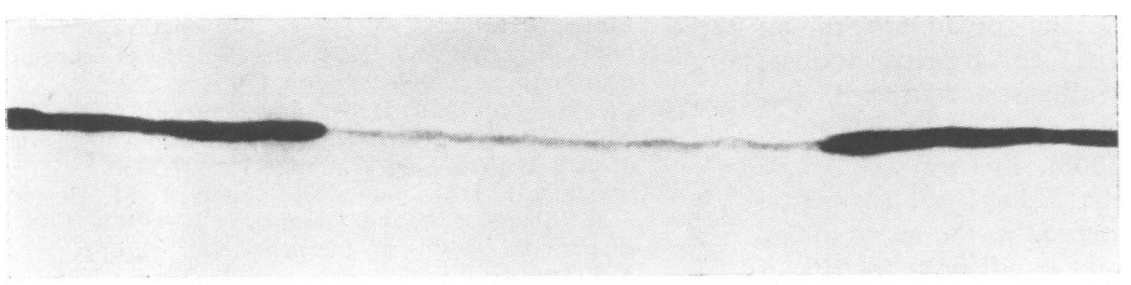

FIG. 1 A single teased nerve fibre stained with osmium tetroxide, illustrating loss of myelin between two nodes of Ranvier. $\times 320$.

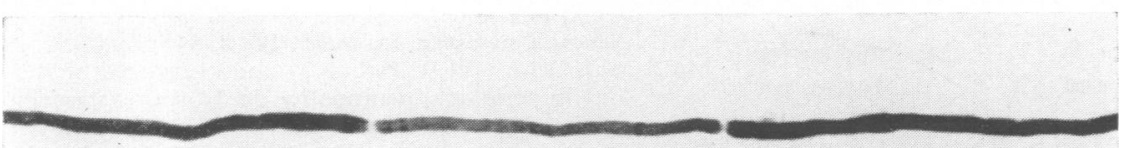

FIG. 2. A single teased nerve fibre stained with osmium tetroxide, illustrating a short remyelinated segment. $\times 320$.

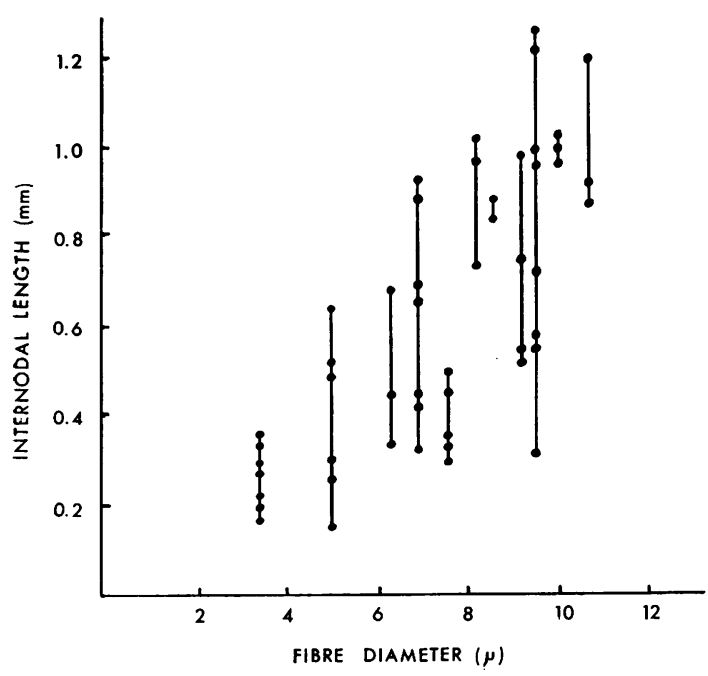

FIG. 3. Relationship between internodal length and fibre diameter in sural nerve from a 27-year-old female with uraemic neuropathy. The internodal lengths from individual fibres are plotted against diameter of widest internodal segment and joined by a vertical line.

neuropathy by repeated dialysis (Tenckhoff et al., 1965; Editorial on uremic neuropathy, 1967) is then explicable. The rapid biochemical changes which occur unmask the latent vulnerability of the sick Schwann cell.

The greater degree of remyelination noted in those dialysed supports the need for more intensive dialysis in subjects with a neuropathy-a finding suggested by others on purely clinical evidence (Tenckhoff et al., 1965; Konotey-Ahulu, Baillod, Comty, Heron, Shaldon, and Thomas, 1965).

The few fibres with Wallerian degeneration were

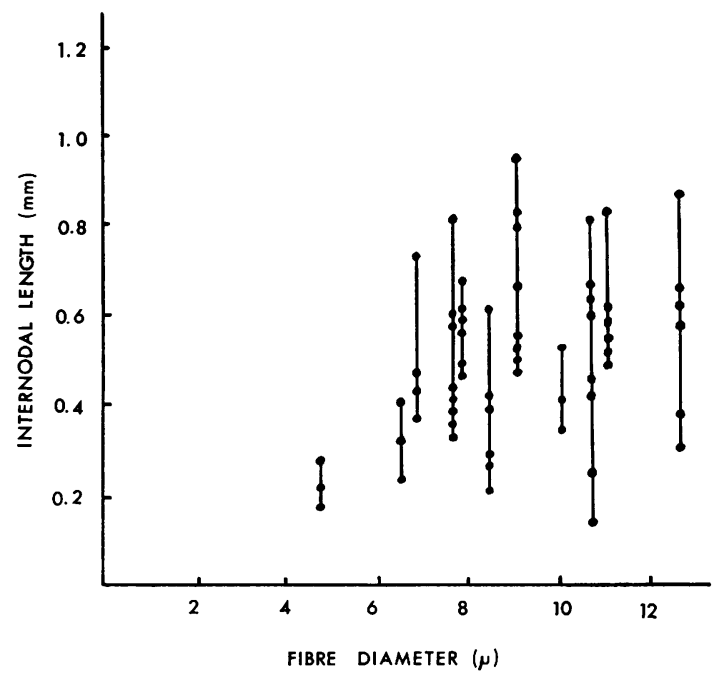

FIG. 4. Relationship between internodal length and fibre diameter in sural nerve from a 30-year-old male with uraemia. Plotted as in Fig. 3.

observed in those cases with marked segmental demyelination. It is our view that repeated episodes of a purely demyelinative process ultimately result in a non-specific destruction to both myelin and axis cylinders.

The aetiology of uraemic neuropathy remains obscure. The degree of demyelination does not depend on blood urea levels, although in each case the level was over $200 \mathrm{mg} / 100 \mathrm{ml}$. Creatinine may be implicated, since an increased retention is found associated with decreasing motor-nerve conduction velocity (Jebsen et al., 1967). In the present study, creatinine was estimated in four subjects (cases 1,7 , $10,12)$. All revealed increased levels with a marked 
degree of demyelination. The possibility of an associated diabetes mellitus, polyarteritis nodosa, amyloidosis, or impaired utilization of the B vitamins is discussed elsewhere (Asbury et al., 1963; Callaghan, 1966; Tyler, 1968). In case 4, amyloid deposits were noted in the kidney but segmental demyelination was not observed in the nerve fibres. Other conditions which may predispose to loss of myelin, were excluded in the remaining cases.

The authors thank Professor W. T. E. McCaughey for advice and encouragement and Mr. F. A. Murray for photographic assistance. One of us (D.L.C.) was supported by a grant from the Medical Research Council of Ireland.

\section{REFERENCES}

Asbury, A. K., Victor, M., and Adams, R. D. (1963). Uremic polyneuropathy. Arch. Neurol. (Chic.), 8, 413-428.

Callaghan, N. (1966). A study of peripheral nerve function in chronic renal failure. Irish J. med. Sci., 6th Ser., 488, 325-331.

Fullerton, P. M., Gilliatt, R. W., Lascelles, R. G., and
Morgan-Hughes, J. A. (1965). The relation between fibre diameter and internodal length in chronic neuropathy. J. Physiol (Lond.), 178, 26P-28P.

Jebsen, R. H., Tenckhoff, H. A., and Honet, J. C. (1967). Natural history of uremic polyneuropathy and effects of dialysis. New Engl. J. Med., 277, 327-333.

Konotey-Ahulu, F. I. D., Baillod, R., Comty, C. M., Heron, J. R., Shaldon, S., and Thomas, P. K. (1965). Effect of periodic dialysis on the peripheral neuropathy of end-stage renal failure. Brit. med. J., 2, 1212-1215.

Lascelles, R. G., and Thomas, P. K. (1966). Changes due to age in internodal length in the sural nerve in man. $J$. Neurol. Neurosurg. Psychiat., 29, 40-44.

McDonald, W. I. (1969). Pathology and disordered physiology in peripheral neuropathy In Modern Neurology, pp 261-271. Edited by S. Locke. Churchill: London.

Preswick, G., and Jeremy, D. (1964). Subclinical polyneuropathy in renal insufficiency. Lancet, 2, 731-732.

Tenckhoff, H. A., Boen, F. S. T., Jebsen, R. H., and Spiegler, J. H. (1965). Polyneuropathy in chronic renal insufficiency. J. Amer. med. Ass., 192, 1121-1124.

Tyler, H. R. (1968). Neurologic disorders in renal failure. Amer. J. Med., 44, 734-748.

Uremic neuropathy. Editorial. (1967). New Engl. J. Med., 277, 371-372.

Vizoso, A. D., and Young, J. Z. (1948). Internodal length and fibre diameter in developing and regenerating nerves. J. Anat. (Lond.), 82, 110-134. 